 P-ISSN 2520-7281 E-SSN 2520-729X \\ E-mail: jabe.journal@um.ac.id \\ http://journal2.um.ac.id/index.php/jabe/
}

\section{The Mediating Role of Attitude toward Money on Students' Financial Literacy and Financial Behavior}

\author{
Nurdian Susilowati ${ }^{1}$ \\ Kardiyem $^{2}$ \\ Lyna Latifah ${ }^{3}$ \\ ${ }^{1,2,3}$ Economics Education, State University of Semarang, Indonesia \\ email: nurdiansusilowati@mail.unnes.ac.id
}

DOI: http://dx.doi.org/10.26675/jabe.v4i2.6622

\begin{abstract}
This research aims at discovering the direct influence of financial literacy on financial behavior; finding out the indirect influence of financial literacy on financial behavior through attitude toward money; and figuring out the direct influence of attitude toward money on financial behavior. This research was conducted at Economics Faculty of State University of Semarang or UNNES with its sample being students who had taken budgeting and financial management courses. The sample was taken using proportionate random sampling and 230 respondents were obtained. The data were collected using questionnaire and they were then analyzed using descriptive analysis and path analysis. Based on the first research result, it was found that financial literacy had direct influence on financial behavior. High financial literacy determined a good financial behavior in the future. Secondly, attitude toward money successfully mediated the influence of financial literacy on students' financial behavior. Thirdly, attitude toward money has a direct influence on financial behavior. In general, students have good financial literacy, attitude towards money, and financial behavior. This allowed them to have a clear priority for their future..
\end{abstract}

Keywords: Financial Behavior, Financial Literacy, Attitude toward Money, Students

\section{INTRODUCTION}

Most students begin to intensively manage their personal finance without their parent's monitoring once they are enrolled to universities. Most of them begin to get themselves familiarized with finance and monetary matters such as paying bills, budgeting, saving, or owning credit card on their own behalf. Currently, students have been a main customer segment for financial products and other financial services. Yet, they still cannot use the products and services optimally since they still have relatively poor financial behavior. In regard to financial behavior, today's students are more likely to spend money, rather than wisely managing their money which includes such activities as planning to invest for the future. Additionally, consumptive behaviors such as spending money for clothes, shoes, facial treatment, and for other fashion accessories seems to be commonly practiced. Therefore, there is a need for them to understand what a good financial behavior is.

Financial behavior is a behavior related to the application of finance. Behavioral finance is a discipline in which various disciplines interact and integrate continuously, making its discussion no longer done isolatedly. Elif Akben-Selcuk (2015) suggests that the aspects of students' financial behavior can be seen 
from their punctuality in paying bills, personal budgeting, and their savings for future. Geographical and cultural conditions can also play a role in shaping this financial behavior.

The issuance of financial products offered by banks and other financial institutions can also shape students' financial behavior. Additionally, financial knowledge (or financial literacy) they learned at their campus can also shape their financial behavior. Shim, Xiao, Barber, \& Lyons (2009) suggest that students' financial behavior is acquired from their learning on finance when studying at universities for years which is more likely to influence their decision making in the future. Lyons investigates the practice of credit card use with 835 students as his sample and finds that sex, ethnicity, financial independence, total amount of debts and credit card influence financial behavior risks. In short, many factors can influence students' financial behavior (Xiao, Tang, \& Shim, 2008).

The first among these factors is financial literacy, i.e. an individual's ability to make decisions in personal financial management. Financial literacy constitutes the knowledge on relevant behavior in managing money to measure knowledge on income, money management, savings and investment, spending, and credit (Mandell, 2009; Xiao, 2014). The International Financial Literacy Surveys explains that financial literacy can be measured using financial management in general, savings and loans, investment, and insurance (Jorgensen \& Savla, 2010; Mandell, 2009). Elif Akben-Selcuk (2015) states that the aspects of students' financial behavior can be seen from their punctuality in paying bills, personal budgeting, and savings for their future. Geographical and cultural conditions can also play a role in shaping this financial behavior.

Sabri, MacDonald, Hira, and Masud (2010) find that financial literacy level influences saving behavior and negatively correlates with financial problems among students. The financial literacy studied at universities can shape financial behavior (Shim, Xiao, Barber, \& Lyons: 2009). Additionally, there is an indirect influence of financial literacy on financial behavior. The mediation is made by attitude toward behavior. Anz \& AC Nielsen (2005) find that long-term financial care and financial focus also influence one's financial ability development.

The second factor is attitude toward money. Tang (1995) argues that attitude toward money can be measured using money ethic scale with 3 attitude components as seen from the affect (money is the root of all evil), cognitive (money is a symbol of success), and behavioral (I manage my money very well) aspects. Mendes-Da-Silva (2016) find that financial attitude leads to financial behavior. High financial literacy will influence financial behavior and students with positive financial will end up having positive financial behavior.

Ajzen (2005) explains that knowledge can influence attitude. Attitude can influence behavior through psychological factors such as self confidence/esteem, belief to change, and belief to prosperity. This means there is a direct and indirect influence between these three variables on behavior. Additionally, financial literacy influences financial attitude. Elif Akben-Selcuk (2015) suggests that attitude toward money is the variable which influences students' financial behavior. Students with positive attitude toward money can report punctual monthly bill payment, make personal budget and determine savings for the future.

Based on the explanation above, this research will investigate; 1) the direct influence of financial literacy on students' financial behavior; (2) the indirect influence of financial literacy on financial behavior through students' attitude toward money; (3) the direct influence of attitude toward money on financial behavior. The difference this research has from the previous studies is its use of attitude toward money variable as an intervening variable. In the previous studies, attitude toward money serves as an independent variable which influences financial behaviour (Mendes-Da-Silva, 2016). According to the planned behavior theory, attitude can shape an individual's behavior both directly and indirectly. Likewise, only the direct influence of financial literacy variable in the previous studies is tested. Meanwhile, in this research both its direct and indirect influences are tested. The financial literacy variable in this research refers to the finding of Hancock et al (2012), i.e. money management in general, saving and loans, investment, and insurance. 


\section{LITERATURE REVIEW AND HYPOTHESES}

Planned Behavior Theory is a further development of Theory of Reasoned Action which uses the basic assumption that humans behave consciously and consider any available information. Ajzen (2005) adds a construct which has not been in the Theory of Reasoned Action, namely perceived behavioral control. This construct is added in an attempt to grasp the limits that individuals have in order to perform certain behaviors. In other words, whether or not a behavior is practiced is not determined merely by attitude and subjective norms, rather it is also determined by individual perceived control of what they can do which comes from their belief of that control (control beliefs). In more detail, Ajzen (2005:133) adds individual's background factors into the Planned Behavior Theory, thus it is schematically depicted as in the figure below.

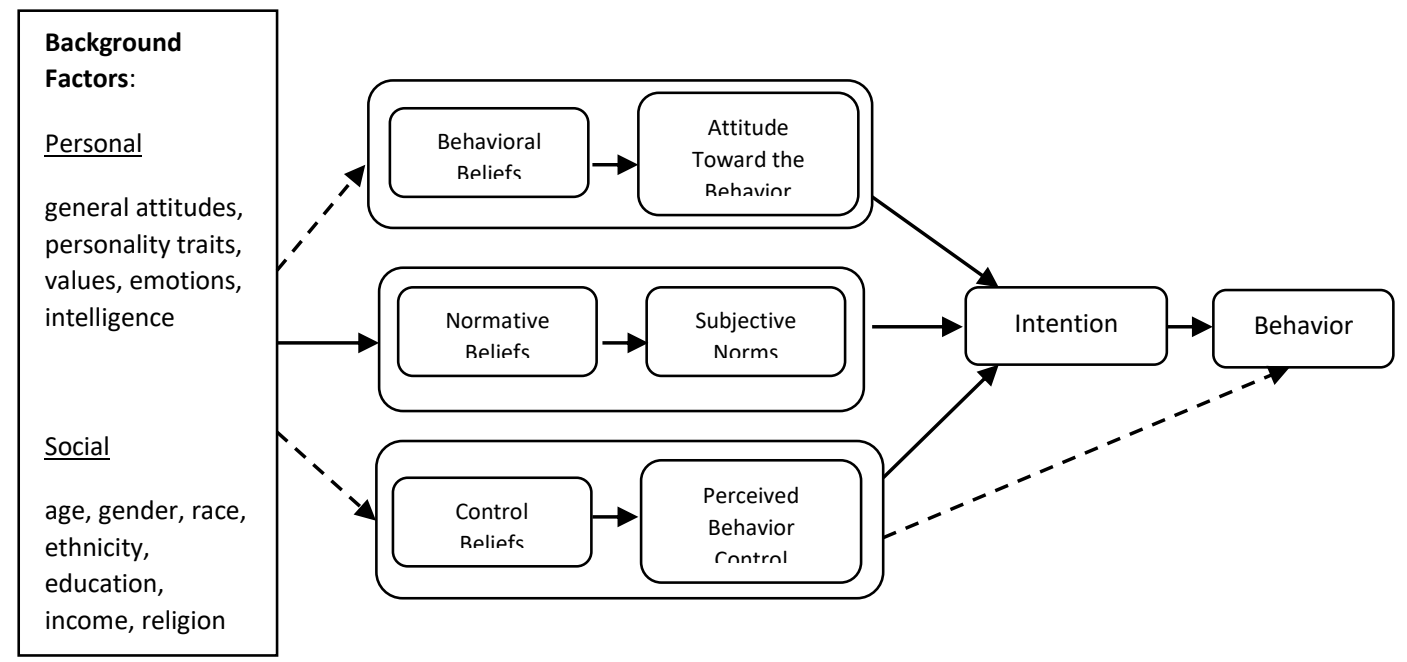

Figure 1. Theory of Planned Behavior (Ajzen, 2005)

Based on the theoretical model from Theory of Planned Behavior, it is explained that background factors (such as age, sex, race, socio-economic status, mood, personality trait, and knowledge) influence individual's attitude and behavior towards something. Behavioral belief is what an individual believes regarding a behavior from both positive and negative sides, attitude towards behavior or tendency to affectly react to a behavior, in the form of like or dislike to that behavior. The normative beliefs directly and expressly related to environmental influence are suggested by Lewin in Field Theory. Subjective norm is defined as to what extent a person is motivated to follow people's view on the behavior to be practiced (normative belief). When an individual think it is his personal right to decide on what he does, and it should not be decided by others around him, then he will ignore others' view on the behavior he is about to practice.

The belief that a behavior can be practiced (control beliefs) is obtained from many things. The first one is the experience of previously practicing the same behavior or the experience acquired from seeing others (for example friends, close relatives) practicing the behavior which leads him to believing that he will also be able to practice it. The second one is the individual's belief that a behavior will be practicable is also determined by the availability of time and facilities to practice that behavior, and ability to deal with each difficulty which may hinder the practice of that behavior. Perceived behavioral control is the belief that an individual has or has never practiced a certain behavior, the individual has the facilities and time to practice that behavior, then the individual estimates their ability whether or not they have what it takes to practice that behavior. Intention to practice the behavior is one's inclination to choose to do or not do a work. 


\section{There is a direct influence of financial literacy on students' financial behavior}

A number of studies show that financial literacy has a positive correlation with financial behavior. Hilgert, Hogart and Beverly (2003) add financial behavior and financial literacy into a questionnaire in the National Survey of Consumer Finances. They make a behavior-based Financial Practice Index into four variables: cash flow management, credit management, saving, and investment behavior, then they compare the indices against financial literacy score and find that those with higher financial literacy level also have higher Financial Practice Index. This indicates a positive relationship between financial behavior and financial literacy despite its unknown causality direction. The causality might be different, in a sense that it is the improvement in financial literacy which causes better or more effective financial behavior and financial decision making or the other way around.

Elif Akben-Selcuk (2015) states that the aspects of students' financial behavior include punctuality in paying bills, personal budgeting, and savings for their future. Geographical and cultural conditions can also play a role in shaping this financial behavior. The financial products offered by banks and other financial institutions can also shape students' financial behavior. Research has shown that financial behavior has a positive influence on improved financial welfare. Sabri, MacDonald, Hira, and Masud (2010) find that financial literacy level influences saving behavior and negatively correlates with financial problems among students. The financial literacy studied at universities can shape financial behavior (Shim, Xiao, Barber, \& Lyons, 2009). Based on the explanation above the first hypothesis of this research is as follows.

$\mathrm{H}_{1}$ : There is a direct influence of financial literacy on students' financial behavior

\section{There is an indirect influence of financial literacy on financial behavior through students' attitude toward money}

Sabri, MacDonald, Hira, and Masud (2010) find from data obtained from 11 universities in Malaysia that financial literacy level influences saving behavior and negatively correlate with financial problems among students. They also find that pre-college financial experience can help shape poor financial habit for students. In a further study, Sabri, Cook, and Gudmundson (2012) find that habit, financial literacy, and financial socialization improve students' financial welfare, including their current financial condition and financial management skills.

Parent's financial attitude and beliefs are also found to have significant influence on their children's financial attitude and beliefs. In socialization particularly, their parents and formal education (universities) influence positively their children's financial literacy, skills and attitude (Lyons et al., 2007; Lyons et al. 2006). Tang (1995) states that financial attitude consists of money ethic scale using 3 attitude components as seen from the affect (money is the root of all evil), cognitive (money is a symbol of success), and behavioral (I budget my moneyvery well) aspects. Furthermore, this financial attitude influences students' financial behaviour. Therefore, the second hypothesis is as follows.

$\mathrm{H}_{2}$ : There is an indirect influence of financial literacy on financial behavior through students' attitude toward money

\section{There is a direct influence of attitude toward money on students' financial behavior}

Mendes-Da-Silva's (2016) research finds that financial attitude leads to financial behavior. Aydin, Elif Asli.,\& Selcuk, Akben Elif (2019) suggest that students with good attitude towards money are more likely to show a good financial behavior. A good financial behavior will also shape a good welfare level. This is because they can take the logical attitude and thinking in managing their money. The financial management performed by students is the personal one such as managing their pocket money for their needs for a month and for savings. The research result also indicates that students save some money when they have some of their monthly pocket money left.

Elif Akben-Selcuk (2015) states that attitude toward money is a variable which influences students' financial behavior. Students with positive attitude toward money can report their punctual monthly bill payment, make personal budget and determine savings for the future. Setiyani, R., \& Solichatun, Ipit (2019) suggest that students' financial attitude influences students' financial behavior. A good attitude will shape a 
good behavior and vice versa. Therefore, when a student has a good financial attitude, it will then lead to a rational financial behavior. This indicates that attitude positively correlates with financial behavior.

$\mathrm{H}_{3}$ : There is a direct influence of attitude toward money on students' financial behavior

\section{METHODS}

This is quantitative research. It was conducted at Economics Faculty of Semarang State University (UNNES). The population in this research were students at Economics Faculty who had taken budgeting and financial management courses. The number of sample to be taken in this research was determined using the following Slovin formula:

$$
n=\frac{N}{1+N e^{2}}
$$

Note:

n : sample size

$\mathrm{N} \quad$ : population size

e $\quad$ : percentage of error tolerance due to a tolerable sampling error. The tolerance percentage used was $5 \%$.

From the formula above, 249 students were taken as the sample. Furthermore, the sample was taken using proportionate random sampling. The sample was distributed based on the proportion of number of students by major using the following formula (Riduan \& Kuncoro, 2011:57):

$$
\mathrm{ni}=\frac{\mathrm{Ni}}{\mathrm{N}} \mathrm{n}
$$

Note:

ni : number of sample by stratum

$\mathrm{n} \quad:$ total number of sample $=249$

$\mathrm{Ni} \quad$ : number of population by stratum

$\mathrm{N} \quad$ : total number of population $=655$

Thus, the total number of population and sample of this research was as follows.

Table 1. Research Population and Sample

\begin{tabular}{clcc}
\hline No & \multicolumn{1}{c}{ Study Program } & Population & Sample \\
\hline 1 & Accounting Education S1 & 186 & 71 \\
2 & Accounting S1 & 237 & 90 \\
3 & Management S1 & 232 & 88 \\
& Total & 655 & 249 \\
\hline
\end{tabular}

Source: Data on students at Economics Faculty, Sikadu (2017)

The dependent variable was financial behavior (FB). The independent variable was financial literacy (FL) and the intervening variable was attitude toward money (ATM). Financial Literacy (FL) is an individual's ability to make decisions in term of managing their personal finance. The indicators of this financial literacy (FL) variable were developed using Hancock et al (2012), i.e. money management in general, saving and loans, investment, and insurance. Meanwhile attitude toward money (ATM) was the disposition to positively or negatively respond to a behavior. The indicators of attitude toward money (ATM) variable were developed from Tang (1995), namely affect (money is the root of all evil), cognitive (money is a symbol of success), and behavioral (I budget my money very well) aspects. Moreover, financial behavior (FB) was a behavior related to the application of financial management. The indicators of financial 
behavior (FB) variable were developed from Elif Akben-Selcuk (2015), namely punctuality in paying bills, personal budgeting, and savings for future.

The data were collected using questionnaire. This questionnaire was distributed in person to collect the data in this research by the lecturers. The collected data were then analyzed using descriptive analysis and path analysis. Descriptive analysis was used to describe or depict the condition of each variable, namely Financial Literacy (FL), Attitude toward Money (ATM), and Financial Behavior (FB). Meanwhile, path analysis was a statistical analysis method which allows researchers to give a quantitative interpretation for the relationship of a number of variables in a model. This path analysis aims at determining the direct and indirect influences between Financial Literacy (FL), Attitude toward Money (ATM), and Financial Behavior (FB) variables.

\section{RESULTS}

From the descriptive analysis result, it was found that the mean for FL variable was 45.99 and it was classified as high since it was within 50-61 range. This meant students had a good financial literacy and thus they could decide on money management in general, decide on saving and loans, decide on investment, and insurance they needed for their future. Furthermore, the mean for FA variable was 37.26 and this was also high for being within 33-40 range. This meant students had a good financial attitude as could be seen from their ability in responding positively and negatively to financial management such as attitude towards money use for daily needs, attitude toward money as a symbol of success, and attitude towards budget use. Finally, the mean for FB variable was 67.35 and it was classified as high. This meant students had a good financial behavior. Students could pay their monthly rent bill punctually, made their personal budget, and had savings for their future.

From the path analysis result, the direct influences proposed in the problem formulation were 1) influence of financial literacy on financial behavior and 2) influence of attitude toward money on financial behavior. py1 value was the standardized coefficients (Beta) value which was obtained from the regression of influence of financial literacy on financial behavior, and the influence of attitude toward money on financial behavior. The Beta value used was the financial literacy and attitude toward money beta. Below was the table of regression coefficients of the influence of financial literacy and financial attitude on financial behavior.

Table 2. Direct Influence of Each Variable

\begin{tabular}{|c|c|c|c|c|}
\hline Model & $\begin{array}{l}\text { Unstandardized } \\
\text { Coefficients (B) }\end{array}$ & $\begin{array}{c}\text { Standardized } \\
\text { Coefficients } \\
\text { (Beta) }\end{array}$ & $\mathbf{T}$ & Sig. \\
\hline (Constant) & 21.137 & & 4.810 & .000 \\
\hline FL & .455 & .385 & 6.545 & .000 \\
\hline ATM & .447 & .234 & 3.908 & .000 \\
\hline
\end{tabular}

a. Dependent Variable: FB

Based on this table of regression coefficients, it was found that py $1=0.385$ and py $2=0.234$. Based on the values of each coefficient, the direct influence of financial literacy on financial behavior could be calculated as follows: Py 1 x Py $1=0.385$ x $0.385=0.148$. Moreover, based on the values of each coefficient, the direct influence of attitude toward money on financial behavior could be counted as follows: Py $2 \times$ Py $2=$ $0.234 \times 0.234=0.055$.

Furthermore, there were 3 indirect influences formulated in the problems earlier, including 1) indirect influence of financial literacy on financial behavior through students' attitude toward money. The result of this regression could be seen in the following table. 
Table 3. Indirect Influence

\begin{tabular}{rrcccc}
\hline \multicolumn{7}{c}{ Coefficients $^{\mathbf{a}}$} \\
\hline \multirow{2}{*}{ Model } & $\begin{array}{c}\text { Unstandardized } \\
\text { Coefficients (B) }\end{array}$ & $\begin{array}{c}\text { Standardized } \\
\text { Coefficients (Beta) }\end{array}$ & T & Sig. \\
\hline $\mathbf{1}$ & (Constant) & 21.137 & & 4.810 & .000 \\
\hline FA & .447 & .234 & 3.908 & .000 \\
\hline
\end{tabular}

Based on the table above, this influence could be seen by seeing the parameters p31 and py 3 with the standardized coefficient (Beta) being 0.213 and 0.234 respectively. Based on the values of each coefficient, the indirect influence of financial literacy on financial behavior through students' attitude toward money could be calculated as follows: $\mathrm{P} 31 \times \mathrm{x}$ py $3=0.213 \times 0.234=0.049$.

In path analysis, there was a term known as total influence. In this case, the total influence was the sum of direct and indirect influences of financial literacy, attitude toward money, and financial behavior variables. Below was the sum of total influence based on the data analysis result. The total influence (direct influence of 1 py $1=0.148$ plus indirect influence of 10.049) was equal to 0.197.

\section{DISCUSSION}

\section{Direct Influence of Financial Literacy on Financial Behavior}

Based on the research result, there was actually a direct influence of financial literacy on financial behavior. This result confirmed Sabri, MacDonald, Hira, and Masud (2010) who found that financial literacy had an influence on students' saving behavior. The financial literacy in the form of knowledge on financial management in general, knowledge on savings and borrowing, investment, and insurance influenced students' financial behavior. The higher the knowledge, the more likely for students to have a better financial behavior. Individuals could decide, plan, and prepare their finance for their future. Predetermined financial planning would facilitate them to take the financial actions and behavior which matched the main priority of that planning. Students' financial literacy was acquired from learning financial management from both parents and courses at university.

Parents played an important leading role in shaping students' financial literacy. It was from the family that a child could determine which financial behavior was good or poor. Therefore, financial management learned from family and parents became the basis for financial literacy in other situation. Additionally, individuals acquired financial literacy from their peers and school. From their socialization intensity, individuals interacted with peers and this could influence the shaping of their behavior. If their peers had a good behavior, then the individual would be a person with a good personality and behavior. Furthermore, financial management learned at schools and universities also determined financial behavior. The learning in courses such as financial management and budgeting at schools and universities could be the basis for planning their future. Tali Te'eni-Harari (2016) suggested that subjective and objective knowledges on finance had an influence on behavior in managing personal finance and socio-economic status and financial welfare.

This was in line with Aydin, Elif Asli., \& Selcuk, Akben Elif (2019) and Setiyani, R., \& Solichatun, Ipit (2019) who found that students with high financial literacy score had a good financial attitude. They also showed a good and thus rational financial behavior. This also indicated that attitude positively correlated with financial behavior. Shim, Xiao, Barber, \& Lyons (2009) found that financial literacy learned during study at universities could shape financial behavior. Financial literacy was highly determinant in decision making of an individual who considered the financial risks to be encountered for the decision they made. This financial decision would be useful in the future, thus an individual could minimize the financial risks. Sibel Dinç Aydemir \& Selim Aren (2017) explained that high financial literacy significantly influenced investment intention risk. Students with high financial literacy were more realistic in regard to risky 
investment. This way, they were financially educated and could eradicate the possibility of taking inappropriate and excessive risks.

\section{Indirect Influence of Financial Literacy on Financial Behavior through Attitude toward Money}

Based on the research result, there was indeed an indirect influence of financial literacy on financial behavior through financial attitude. Ajzen (2015) in Planned Behavior Theory explained that individual background, in the form of knowledge, influenced their attitude and behavior towards something. These background factors were basically the characteristics existing within oneself, which in Kurt Lewin's model was classified into $\mathrm{O}$ (organism) aspect. One of these background factors was information in the form of knowledge. Financial attitude was an intervening variable which successfully mediated the influence of financial literacy influence on students' financial behavior. The financial attitude took the form of (1) affect, i.e. money is the root of all evil; (2) cognitive, i.e. money is a symbol of success; (3) behavior, i.e. I budget my money very well. Students could positively and negatively responded to an action, thus they could decide on what financial behavior they would follow and practice.

This research confirmed Mendes-Da-Silva (2016) who found that financial attitude determined financial behavior. Elif Akben-Selcuk (2015) suggested that attitude toward money was the variable which influenced students' financial behavior. Students with positive attitude toward money could report their monthly bill payment punctually, made personal budget and decided on their saving for their future. Therefore, financial planning became the main factor for students to achieve financial welfare in the future. Well-planned finance would lead to a systematic and cost-efficient life. Thus, their financial behavior would be good.

Aydin, Elif Asli.,\& Selcuk, Akben Elif (2019) found that students with higher financial literacy level and good attitude towards money were more likely to exhibit desirable financial behavior. It did not just improve the financial literacy level, rather it also improved the individual attitude toward financial issues and were more likely to be engaged in desirable financial behavior such as paying bills punctually and maintaining balanced budget. In addition to its impact on financial literacy and attitude, it also affected money use ethic. Students with high score for "budget" dimension were more likely to indicate preferred financial behavior. This meant it was important to recognize the role of money as an important component of financial planning and personal fund allocation. Tali Te'eni-Harari (2016) found that students with high financial literacy would also showed positive attitude towards saving behavior.

\section{Direct Influence of Attitude toward Money on Financial Behavior}

There was a direct influence of attitude toward money on financial behavior. This research confirmed Mendes-Da-Silva (2016) who found that financial attitude led to financial behavior. Ajzen (2005) suggested that attitude was a disposition to respond positively or negatively to a behavior. Tang (1995) explained that financial attitude was measured using money ethic scale with 3 attitude components as seen from affect (money is the root of all evil), cognitive (money is a symbol of success), and behavioral (I budget my money very well) aspects.

Students' financial behavior in the form of paying bills punctually, preparing personal budget, and owning savings for future became the basis for financial behavior in the future. Elif Akben-Selcuk (2015) stated that attitude toward money was a variable which influenced students' financial behavior. Students with positive attitude toward money could report punctual monthly bill payment, made personal budget and decided on the saving for their future. Putri, Riska Ayuni., \& Asrori (2018) found that students with positive attitude toward moiney could manage their finance well, and students with negative attitude toward money failed to manage their personal finance well. Therefore, to achieve high financial literacy there was a need for positive attitude toward money.

Ajzen (2005) suggested that attitude was a disposition to respond positively or negatively to a behavior. Attitude to a behavior was determined by the belief on the consequence of that behavior and this was commonly known as behavioral beliefs. Behavioral beliefs connected behavior to the outcome which might be acquired from that behavior. Attitude toward behavior was determined by individual evaluation of 
the outcome related to that behavior and to the power of relationship between those two. Generally speaking, the more positive the consequence of a behavior when students evaluated it, the more likely for these students to have favorable attitude to that behavior; and on the contrary, the more negative the evaluation that a student had of that behavior, the more likely for them to show unfavorable attitude toward that behavior.

Attitude toward behavior was defined as the degree of positive or negative assessment of an individual toward a certain behavior. Attitude toward behavior was determined by the combination of behavioral belief and outcome evaluation. Behavioral belief was an individual's belief regarding the positive or negative consequence of a certain behavior and outcome evaluation was an individual's evaluation of the consequence he/she would receive from a behavior. It could then be concluded that individuals who believe that a behavior could produce positive outcome would have positive attitude toward a behavior, and vice versa.

\section{CONCLUSION}

Based on the research result, it could be concluded as follows. Firstly, the mean values of financial literacy, attitude toward money, and financial behavior variables were relatively high. This meant students had good financial literacy, attitude towards financial management, and financial behavior. For this reason, students had a clear priority for their future. Secondly, there was a direct influence of financial literacy on financial behavior. Attitude toward money successfully moderated the influence of financial literacy on students' financial behavior. The total influence of these variables was $19.7 \%$, meaning that there were other variables which could be revealed for further studies. The initial step to improve financial management was by making personal budget to allow the individual to have a good financial planning. In this research, only cognitive and attitude domains were tested and no psychological domain had been studied. It was therefore recommended for further research to investigate psychological domain such as financial belief. Financial belief was one's believe on their own ability to manage their money well.

\section{REFERENCES}

Ajzen, I \& Fishbein, M. 2005. The influence of attitudes on behavior. The Handbook of Attitudes. Albarracin, D, Johnson, BT, and Zanna, MP (Eds.). Mahwah, NJ, Erlbaum: 173 - 221

ANZ and AC Nielsen. 2005. Understanding Personal Debt \& Financial Difficulty in Australia. http://www.anz.com.au/resources/2/6/26028f804d2bd4f282339b69785e67b9/ANZ_UPD_fin_difficult y.pdf?MOD=AJPERES

Aydin, Elif Asli.,\& Selcuk, Akben Elif. 2019. An Investigation of Financial Literacy, Money Ethics and Time Preferences Among College Students: A Structural Equation Model. International Journal of Bank Marketing. https://doi.org/10.1108/IJBM-05-2018-0120

Baker, H.K., \& Nofsinger, J. R. 2010. Behavioral Finance: Investors, Corporations, and Markets. https://books.google.co.id/books?id=ZPhYDwAAQBAJ

Elif, Akben-Selcuk. 2015. Factors Influencing College Students' Financial Behaviors in Turkey: Evidence from a National Survey. International Journal of Economics and Finance, Vol. 7, No. 6

Garg, Neha., \& Singh, Shveta. 2016. Financial Literacy Among Youth. International Journal of Social Economics, https://doi.org/10.1108/IJSE-11-2016-0303

Hilgert, M.A., Hogart, J. M., \& Beverly, S.G. 2003. Household Financial Management: The Connection Between Knowledge and Behavior. 
Jorgensen, B. L., \& Savla, J. 2010. Financial Literacy of young Adults: The Importance of Parental Socialization. Family Relations, 59(4), 465-478. http://dx.doi.org/10.1111/j.1741-3729.2010.00616.x

Lyons, A.C., Palmer, L., Jayaraten, K. S. U., \& Scherph, E. 2016. Are We Making the Grade? A National Overview of Financial Education and Program Evaluation. The Journal of Consumer Affair, 40(2), 208-235. https://doi.org/10.1111/j.1745-6606.2006.00056.x

Lyons, A.C., Rachlis, M., \& Scherpf, E. 2007. What's in a Score? Differences in Consumers' Credit Knowledge Using OLS and Quantile Regressions. The Journal of Consumer Affair. 41(2), 223-249. https://doi.org/10.1111/j.1745-6606.2007.00079.x

Mandell, L. 2009. The Financial Literacy of Young American Adults: Results of the 2008 National Jump\$tart Coalition Survey of High School Seniors and College Students. Washington, DC: Jumpstart Coalition. Retrieved from http://www.jumpstart.org/assets/files/2008SurveyBook.pdf

Mendes-Da-Silva, Ani Caroline Grigion Potrich Kelmara Mendes Vieira Wesley. 2016. Development of a Financial Literacy Model for University Students. Management Research Review, Vol. 39 Iss 3 pp. http://dx.doi.org/10.1108/MRR-06-2014-0143

Putri, Riska Ayuni., \& Asrori. 2018. Determinan Literasi Finansial Dengan Gender Sebagai Variabel Moderasi. Economic Education Analysis Journal, Vol 7 No 3

Riduan \& Kuncoro. (2011). Cara Menggunakan dan Memakai Path Analysis (Analisis Jalur). Bandung: Alfabeta

Riitsalu, Leonore., \& Murakas, Rein. 2019. Subjective Financial Knowledge, Prudent Behaviour and Income: The preDIctors of Financial Well-Being in Estonia", International Journal of Bank Marketing, https://doi.org/10.1108/IJBM-03-2018-0071

Sabri, M. F., Cook, C. C., \& Gudmunson, C. G. 2012. Financial Well Being of Malaysian College Students. Asian Ed and Dev Studies, 1(2), 153-170. http://dx.doi.org/10.1108/20463161211240124

Sabri, M. F., MacDonald, M., Hira, T. K., \& Masud, J. 2010. Childhood Consumer Experience and the Financial Literacy of College Students in Malaysia. Family and Consumer Sciences Research Journal, 38(4), 455-467. http://dx.doi.org/10.1111/j.1552-3934.2010.00038.x

Setiyani, Rediana., \& Solichatun, Ipit. 2019. Financial Well-Being of College Students: An Empirical Study on Mediation Effect of Financial Behavior. Conference Paper 3rd ICEEBA International Conference on Economics, Education, Business and Accounting Volume 2019

Sibel Dinç Aydemir \& Selim Aren. 2017. Do The Effects Of Individual Factors on Financial Risk-Taking Behavior Diversify With Financial Literacy?. Kybernetes, Vol. 46 Issue: 10, pp.1706-1734, https://doi.org/10.1108/K-10-2016-0281

Shim, S., Xiao, J.J., Barber, B.L., \& Lyons A.C. 2009. Pathways to Life Success: A Conceptual Model of Financial Well-Being for Young Adult. Journal of Applied Developmental Psychology. Vol. 30, No. 6, pp. 708-723. https://doi.org/10.1016/j.appdev.2009.02.003

Tali Te'eni-Harari. 2016. Financial Literacy Among Children: The Role of Involvement in Saving Money. Young Consumers, Vol. 17 Issue: 2, pp.197-208, https://doi.org/10.1108/YC-01-2016-00579

Tang, T. L. 1995. The Development of a Short Money Ethic Scale: Attitudes Toward Money And Pay Satisfaction Revisited. Personality and individual Differences, 19(6), 809-816. http://dx.doi.org/10.1016/s0191-8869(95)00133-6

Xiao, J. J., Tang, C., \& Shim, S. 2008. Acting for happiness: Financial Behavior and Life Satisfaction of College Students. Social Indicators Research, 92, 53-68. http://dx.doi.org/10.1007/s11205 008-9288-6 
Xiao, J. J., Ahn, S. Y., Serido, J., \& Shim, S. 2014. Earlier Financial Literacy and Later Financial Behaviour of College Students. International Journal of Consumer Studies, 38(6), 593-601. http://dx.doi.org/10.1111/ijcs.12122 Volpe, R. P., Chen, H., \& Pavlicko, J. J.

Xiao, JJ \& Wu, J. 2008. Completing Debt Management Plans in Credit Counseling: An Application of the Theory of Planned Behavior. Journal of Financial Counselling and Planning, Vol. 19, no. 2, pp. 2946. 